\title{
ANALISIS KESALAHAN PENGGUNAAN AFIKS DALAM MAKALAH MAHASISWA SEMESTER 1 PROGRAM STUDI PENDIDIKAN BAHASA INDONESIA UNIVERSITAS AL ASYARIAH MANDAR
}

\author{
Adelia Sulastri ${ }^{1}$, Nur Hafsah Yunus MS ${ }^{*}$, Rini Riniawati ${ }^{2}$ \\ IUniversitas Al Asyariah Mandar, ${ }^{2}$ Universitas Bina Sarana Informatika \\ *Email: Hafsahnur29@gmail.com
}

\begin{abstract}
This research is based on the problem of the many errors in the use of affixes in students' papers or scientific papers. This affects the various changes in meaning caused by affixes. This study aims to describe the errors in the use of affixes contained in the first semester student papers in the Indonesian language study program at Univeristas Al Asyariah Mandar. This type of research is descriptive qualitative. The instrument used in this study was the human instrument. The data collection technique used is the note taking technique. The object under study is a paper written by a student. The results showed that from 14 research sources 32 data were produced and there were three types of errors in the use of affixes, namely prefixes, confixes, and simulfices. As for the prefix error, which is 1 error or $3.13 \%$, there are 18 errors or $56.25 \%$ and 1 error or $3.13 \%$. Errors in the use of confixes, namely as many as 1 error or $3.13 \%$, and as many as 8 errors or $25.00 \%$ and in-i as much as 1 error or 13.13\%. Error in using simulfix, which is 2 errors or $6.25 \%$. Based on the results of data analysis that has been done, it can be concluded that students make a lot of mistakes in the use of preprefixes. In addition, various spelling errors were also found. Therefore, mastering affixes and spelling needs to find a solution.
\end{abstract}

Keywords: analysis, errors, use of affixes

\section{PENDAHULUAN}

Bahasa adalah suatu sistem lambang berupa bunyi, bersifat arbitrer, digunakan oleh suatu masyarakat tutur untuk bekerja sama, berkomunikasi dan untuk mengidentifikasikan diri (1998:1). Bahasa sendiri dipelajari dengan tujuan sebagai salah satu alat komunikasi antar manusia di dalam kehidupan bermasyarakat. Kridalaksana (dalam Rohmadi, 2012:1) menjelaskan dalam Kamus Linguistik bahwa Linguistik (linguistic) adalah ilmu bahasa.

Dalam linguistik umum, terdapat empat objek kajian yang dibahas di dalamnya, yaitu fonologi, morfologi, sintaksis dan semantik. Fonologi adalah salah satu subdisiplin ilmu linguistik yang mengkaji bunyi-bunyi bahasa. Morfologi 
merupakan bagian dari linguistik yang mempelajari susunan konstituen kata yang terdiri atas morfem. Morfem itu bergabung menjadi kata menurut kaidah gramatikal tertentu Verharr dalam (Kadjia, 1998:5). Selanjutnya, Sintaksis adalah subdisiplin ilmu linguistik yang mengkaji struktur bahasa. Dan yang terakhir semantik adalah subdisiplin ilmu linguistik yang mengkaji makna bahasa.

Afiksasi adalah proses pembubuhan afiks pada suatu bentuk baik berupa tunggal maupun bentuk kompleks untuk membentuk kata-kata baru (Rohmadi, 2012:41). Afiks ialah suatu bentuk linguistik yang keberadaanya hanya untuk melekatkan diri pada bentuk-bentuk lain sehingga mampu menimbulkan makna baru terhadap bentuk-bentuk yang dilekatinya. Afiksasi atau pengimbuhan adalah proses pembentukan kata dengan membubuhkan afiks (imbuhan) pada bentuk dasar, baik bentuk dasar tunggal maupun kompleks. Dalam pembentukan kata dengan proses afiksasi, afiksasilah yang menjadi dasar untuk membentuk kata.

Pada berbagai karya tulis, misalnya makalah yang ditulis mahasiswa terdapat berbagai perubahan makna yang diakibatkan oleh afiks. Oleh karena itu, peneliti tertarik untuk mengkaji secara mendalam mengenai afiksasi sehingga peneliti memiliki gagasan untuk meneliti proses afiksasi yakni prefiks, sufiks, infiks, dan konfiks yang berkategori verba dalam tugas makalah pada mahasiswa Bahasa Indonesia.

\section{Pengertian Analisis}

Dalam Kamus Bahasa Indonesia Kontemporer karangan Peter Salim dan Yenni Salim (2002) menjabarkan pengertian analisis sebagai berikut:

1. Analisis adalah penyelidikan terhadap suatu peristiwa (perbuatan, karangan dan sebagainya) untuk mendapatkan fakta yang tepat (asal usul, sebab, penyebab sebenarnya, dan sebagainya).

2. Analisis adalah penguraian pokok persoalan atas bagian-bagian, penelaahan bagian-bagian tersebut dan hubungan antar bagian untuk mendapatkan pengertian yang tepat dengan pemahaman secara keseluruhan.

3. Analisis adalah penjabaran (pembentangan) sesuatu hal, dan sebagainya setelah ditelaah secara seksama.

4. Analisis adalah proses pemecahan masalah yang dimulai dengan hipotesis (dugaan, dan sebagainya) sampai terbukti kebenarannya melalui beberapa kepastian (pengamatan, percobaan, dan sebagainya).

5. Analisis adalah proses pemecahan masalah (melalui akal) ke dalam bagianbagiannya berdasarkan metode yang konsisten untuk mencapai pengertian tentang prinsip-prinsip dasarnya.

\section{Bahasa}

Bahasa merupakan lambang bunyi yang arbitrer yang dipergunakan oleh para anggota kelompok sosial untuk bekerjasama, berkomunikasi, dan mengidentifikasi diri (Achmad, dkk., 2012:3). Bahasa itu meliputi dua bagian 
yaitu bunyi yang dihasilkan oleh alat-alat ucap dan arti (makna) yang tersirat dalam arus bunyi (Keraf, 1984: 15). Dari beberapa pendapat tersebut dapat disimpulkan bahwa bahasa merupakan lambang bunyi yang arbitrer yang dihasilkan oleh alat ucap dan memiliki arti (makna) tersirat diperuntukkan oleh anggota kelompok sosial untuk bekerjasama, berkomunikasi, dan mengidentifikasi diri.

Morfologi

Morfologi ialah cabang tata bahasa yang membicarakan hubungan gramatikal bagian-bagian intern kata (Soegijo, 1989:4). Menurut Ramlan morfologi adalah bagian dari ilmu bahasa yang membicarakan atau mempelajari seluk beluk bentuk kata kerja serta pengaruh perubahan bentuk kata terhadap golongan dan arti kata (2012:20). Sejalan dengan pendapat sebelumnya, Keraf (1984:51) berpendapat bahwa morfologi adalah bagian dari tata bahasa yang membicarakan bentuk kata. dari beberapa pendapat di atas dapat disimpulkan bahwa morfologi adalah cabang ilmu tata bahasa yang membicarakan hubungan gramatikal bagian-bagian intern kata serta pengaruh perubahan bentuk kata terhadap golongan dan arti kata.

Hakikat Afiks

Pengertian afiks dikemukakan oleh sejumlah ahli berdasarkan pemahamannya masing-masing. Afiks adalah bentuk morfem terikat yang dipakai untuk menurunkan kata (Alwi dkk., 2003: 31). Chaer (2008: 23) mendefinisikan bahwa afiks adalah morfem yang tidak dapat menjadi dasar dalam pembentukan kata, tetapi hanya menjadi unsur pembentuk dalam proses afiksasi. Ramlan (2012: 57) mengemukakan bahwa afiks adalah suatu satuan gramatikal yang di dalam satu kata merupakan unsur yang bukan kata, dan bukan pokok kata, yang memiliki kesanggupan melekat pada satuan lain untuk membentuk kata baru.

Menurut Kamus Besar Bahasa Indonesia (KBBI), afiks adalah bentuk terikat yang apabila ditambahkan pada kata dasar atau bentuk dasar akan mengubah makna gramatikal (seperti prefiks, infiks, konfiks, atau sufiks). Mulyono (2013: 75) mengemukakan bahwa afiks adalah bentuk linguistik yang terikat baik secara morfologis maupun secara semantik. Menurut Muslich (2008: 41), afiks ialah bentuk kebahasaan terikat yang hanya mempunyai arti gramatikal, yang merupakan unsur langsung suatu kata yang memiliki kesanggupan untuk membentuk kata baru. Dengan demikian, afiks ialah morfem terikat yang bukan kata, bukan juga pokok kata yang memiliki kesanggupan melekat pada kata lain untuk membentuk kata baru.

\section{METODE PENELITIAN}

\section{Jenis Penelitian}

Jenis penelitian yang digunakan dalam penelitian ini adalah deskriptif kualitatif. Deskriptif kualitatif adalah penelitian yang menggunakan latar 
alamiah, dengan maksud menafsirkan fenomena yang terjadi dan dilakukan dengan jalan melibatkan berbagai metode yang ada (Moleong, 2017:5).

\section{Data dan Sumber Data}

Sumber data adalah subyek dari mana data diperoleh. Menurut Lofland (dalam Moleong, 2008: 157) sumber data utama dalam penelitian kualitatif adalah kata-kata, dan tindakan, selebihnya adalah tambahan seperti dokumen dan lainnya. Sumber data dalam penelitia ini adalah seluruh Makalah mata kuliah Linguistik mahasiswa semester I yang berjumlah 14 makalah. Data dalam penelitian ini berupa kalimat-kalimat yang mengandung kesalahan penggunaan afiks yang dimuat dalam makalah Linguistik.

\section{Instrumen Penelitian}

Instrumen penelitian adalah alat pengumpul data dalam sebuah penelitian (Moleong, 2011:168). Instrumen penelitian dalam penelitian ini adalah peneliti sendiri atau human instrument yang berperan sebagai (1) perencana, (2) pelaksana, (3) pengambil data, (4) penganalisis, (5) penafsir dan sekaligus pelapor hasil penelitian. Pengetahuan dan wawasan kebahasaan peneliti khususnya teori tentang tindak tutur menjadi kunci pokok dalam keberhasilan penelitian.

\section{Teknik Pengumpulan Data}

Sugiyono (2008: 63) mengemukakan ada empat teknik pengumpulan data, yaitu observasi, wawancara, dokumentasi, dan gabungan. Secara khusus teknik yang digunakan dalam penelitian ini adalah teknik dokumentasi atau teknik pemanfaatan dokumen. Dokumen yang digunakan dalam penelitian ini adalah makalah mahasiswa semester I.

Pengumpulan data merupakan proses yang berlangsung sepanjang penelitian dengan menggunakan seperangkat instrumen yang telah dipersiapkan guna memperoleh informasi data melalui teknik catat. Dalam hal ini yang dipersiapkan adalah data atau hal-hal yang dianggap penting terkait dengan aspek analisis penggunaan kesalahan afiks.

Teknik catat adalah teknik atau cara yang digunakan untuk mencatat datadata yang ditemukan ke dalam nota pencatat data. Setelah data terkumpul data dianalisis dengan menggunakan metode kualitatif.

Adapun langkah-langkah yang dilakukan oleh peneliti dalam mengumpulkan data adalah sebagai berikut.

1. Peneliti membaca seluruh Makalah.

2. Peneliti menandai dengan menggaris bawahi kata-kata yang mengandung kesalahan penggunaan afiks. 


\section{Teknik Analisis Data}

Analisis data adalah upaya yang dilakukan dengan jalan bekerja data, mengorganisasikan data, memilih-milahnya menjadi satuan yang dapat dikelola, mencari dan menemukan pola, menemukan apa yang penting dan apa yang dipelajari, serta memutuskan apa yang dapat diceritakan kepada orang lain Bogdan \& Biklen (dalam Moleong, 2008: 248). Teknik analisis data yang digunakan dalam penelitian ini adalah data kualitatif. Teknik ini digunakan untuk mendeskripsikan hasil rumusan masalah pada bab 1. Setelah data terkumpul langkah selanjutnya yang dilakukan oleh peneliti menganalisis data yang sudah ada. Langkah-langkah analisis data dalam penelitian ini adalah sebagai berikut.

1. Mengelompokkan kesalahan penggunaan afiks sesuai dengan jenisnya

2. Mengidentifikasi kesalahan penggunaan afiks berdasarkan jenisnya, yang meliputi kesalahan penggunaan prefiks, kesalahan penggunaan sufiks, kesalahan penggunaan konfiks dan kesalahan penggunaan simulfiks.

3. Menjelaskan kesalahan penggunaan afiks pada makalah berdasarkan jenis - jenis afiks.

4. Memperbaiki kesalahan penggunaan afiks

5. Menghitung jumlah kesalahan penggunaan afiks, yaitu kesalahan penggunaan prefiks, kesalahan penggunaan sufiks, kesalahan penggunaan konfiks dan kesalahan penggunaan simulfiks.

6. Membuat kesimpulan

\section{HASIL DAN PEMBAHASAN}

\section{Kesalahan Penggunaan Afiks \\ Prefiks}

Prefiks meN-

pada makalah mahasiswa terdapat kesalahan prefiks meN-. Mahasiswa meluluhkan fonem [b] pada kata "memedakan". Kesalahan tersebut tampak pada kutipan di bawah ini.

alam dari benda yang ditunjuk. Petrus Hispanus,memasukkan psikologi dalam analisis makna bahasa, memedakan nomen atas dua macam yaitu nomen substantivum dan nomen edjektivum,membedakan semua bentuk yang menjadi subjek/predikat dan bentuk tutur lainnya.

Kesalahan pada kata "memedakan" pada kalimat di atas karena meluluhkan fonem [b]. Prefiks meN- dapat bebentuk me-, mem-, meny-, 
meng-, dan menge- tetapi dengan aturan-aturan tertentu. Alomorf memdigunakan apabila bentuk dasarnya diawali dengan fonem $[\mathrm{b}],[\mathrm{p}],[\mathrm{f}]$, dan [v]. Jadi, kalimat yang benar pada kutipan di atas adalah "Petrus Hispanus memasukkan psikologi dalam analisis makna bahasa, membedakan nomen atas dua macam..."

\section{Prefiks di-}

Beberapa kesalahan penggunaan prefiks di- pada makalah mahasiswa tampak pada kutipan berikut ini.

Kata linguistic berasal dari bahasa latin "lingua" yang artinya bahasa. Menurut Kridalaksana (1993) dalam kamusnya kamus linuistik, kata linguistic di definisikan sebagai ilmu tentang bahasa atau penyelidikan bahasa secara ilmiah. Definisi yang sama di kemukakan oleh Tarigan (1986), yaitu seperangkat ilmu pengetahuan yang diperoleh dengan jalan penerapan metode ilmiah terhadap fenomena bahasa. Sebagai penyelidikan bahasa secara ilmiah,

Pada makalah mahasiswa ditemukan kesalahan pada kata "di definisikan" dan "di kemukakan". Penggunaan prefiks di- pada kata "di definisikan" tidak benar karena prefiks di- dilafalkan dan ditulis serangkai dengan kata yang mengikutinya atau diimbuhinya. Fungsi prefiks di- adalah membentuk kata kerja pasif pada sebuah kalimat sedangkan kata kerja aktif menggunakan prefiks ber-. Oleh karena itu, penulisan yang benar pada kalimat yang tersebut, yaitu "kata linguistik didefinisikan sebagai ilmu tentang bahasa" dan "definisi yang sama dikemukakan oleh Tarigan".

\section{Prefiks ke-}

dalam menyelediki kereguleran bahasa yunani .buku dionysius tharax ini lahir kurang tahun 100 S.M buku ini diterjemahkan kedalam bahasa latin oleh remmius palaemon pada permulaan abad pertama masehi dengan judul ars grammatika. buku inilah yang kemudian dijadikan model

Pada kutipan kalimat di atas terdapat kesalahan pada penggunaan ke-. Maksud pada kata "kedalam" merujuk pada suat tempat. Bila ditulis serangkai, prefiks ke- hanya digunakan dalam bahasa ragam tidak baku. Fungsi dan makna gramatikalnya sepadan dengan verba berprefiks ter-. Jadi, penulisan yang tepat pada kalimat tersebut adalah "buku ini diterjemahkan ke dalam bahasa latin oleh remmius palaemon pada permulaan abad pertama masehi dengan judul ars grammatika" 


\section{Konfiks}

Konfiks per-an

Studi bahasa pada zaman pertengahan mendapat pehatian penuh terutama oleh para filsuf skolastik.Pada zaman pertengahan ini,yang patut dibicarakan dalam studi bahasa antara lain adalah peranan kaum modistae ,Tata

Pada kutipan makalah di atas terdapat kesalahan pada konfiks per-an. penulisan kata "pehatian" tidak benar karena bentuk dasar kata tersebut adalah hati (hati-hati) dan diawali dengan fonem [h]. Bentuk atau alomorf pean digunakan jika diturunkan dari dasar melalui verba berbentuk be-. Sementara itu, pada kutipan di atas bukan verba berbentuk be-. Jadi, bentuk yang benar pada kalimat/kutipan tersebut adalah "studi bahasa pertengahan mendapat perhatian penuh terutama oleh para filsuf skolastik".

\section{Simulfiks}

\section{Simulfiks diper-}

dengan benda yang di tunjukanya atau dengan kata lain,setiap kata mempunyai makna secara alami ,secara fisis . misanya, kata-kata yang di sebut onomatope,atau kata yang terbentuk berdasarkan peniruan buryi .sebaliknya dalam kelompok lain,atau kelompok konfensional,berpendapat bahwa bahasa bersifat konfensi artinya,maka-makna kata itu di peroleh dari hasil-basil tradisi

Pada kutipan tersebut, terdapat kesalahan penulisan simulfiks di-per-. Kesalahan tersebut terdapat pada kata "di peroleh". Bentuk dasar pada kata tersebut adalah oleh dengan kelas kata verba. Penulisan yang benar jika diawali dengan prefiks di-per- dan berbentuk verba pasif harus disambung. Jadi, penulisan yang tepat untuk kalimat di atas adalah "diperoleh".

Tabel 1. Persentase kesalahan penggunaan afiks

Afiks

Jumlah Kesalahan

Persentasi

(\%)

Prefiks

meN-

1

di-

18

56,25

ke-

1

3,13 
Konfiks

$$
\text { per-an }
$$

di-kan

di-i

diper-

Jumlah
1

8

1

2

32
3,13

25,00

3,13

6,25

Kesalahan-kesalahan penggunaan afiks yang ditemukan dalam penelitian ini, yaitu prefiks, konfiks, dan simulfiks. Adapun kesalahan penggunaan prefiks, yaitu $m e N-$, di-, dan $k e-$. Kesalahan penggunaan konfiks, yaitu per-an dan di-kan. Lalu, kesalahan penggunaan simulfiks, yaitu diper-. Kesalahan tersebut diperoleh dari hasil telaah yang dilakukan secara intensif pada karya tulis (makalah) mahasiswa.

Dari tiga jenis kesalahan penggunaan afiks yang ditemukan, kesalahan afiks paling banyak ditemukan pada penggunaan prefiks di-. Kesalahan penggunaan prefiks berjumlah 19 data dari 32 kesalahan yang ditemukan. Kesalahan penggunaan afiks disebabkan oleh kurangnya pengetahuan mengenai perbedaan prefiks di- dan preposisi di. Prefiks di- tidak memiliki berbagai variasi bentuk dan yang perlu diperhatikan $d i$ - sebagai prefiks dan $d i$ sebagai kata depan atau preposisi.

Selanjutnya, kesalahan penggunaan prefiks meN- sebanyak 1 kesalahan. Kesalahan tersebut terjadi karena mahasiswa meluluhkan fonem [b] setelah diawali dengan prefiks meN-, dalam kajian linguistik pada tataran morfologi, bunyi atau fonem yang luluh/lebur adalah fonem $[\mathrm{k}],[\mathrm{p}],[\mathrm{s}]$, dan $[\mathrm{t}]$ jika diawali dengan prefiks meN-

Kesalahan afiks selanjutnya, yaitu prefiks ke-. Jumlah kesalahan tersebut sebanyak 1 kesalahan. Bila ditulis serangkai, prefiks ke- hanya digunakan dalam bahasa ragam tidak baku. Fungsi dan makna gramatikalnya sepadan dengan verba berprefiks ter-. Jadi, makna gramatikal yang dimilikinya, yaitu tidak sengaja, dapat di, dan kena. Misalnya, kebalik, kebawa, dan sebagainya.

Dari beberapa kasus kesalahan yang dilakukan oleh mahasiswa dalam tulis ilmiah yang telah disusun maka diperlukan suatu solusi untuk mengatasi hal tersebut. Berkaitan dengan penelitian yang relevan pada Bab I menunjukkan kesalahan penggunaan afiks yang meliputi kesalahan prefiks, kesalahan sufiks, kesalahan konfiks maka dalam penelitian ini juga ditemukan 3 kesalahan afiks. 
Kesalahan tersebut, yaitu prefiks, konfiks, dan simulfiks. Jika diperinci lagi maka kesalahan mahasiswa pada prefiks, yaitu prefiks meN-, di-, dan -kan. Kesalahan pada konfiks, yaitu per-an dan di-kan. Terakhir, pada kesalahan simulfiks, yaitu diper-.

\section{SIMPULAN}

Berdasarkan hasil penelitian dan pembahasan dalam penelitian ini maka dapat disimpulkan bahwa kesalahan penggunaan afiks lebih banyak terdapat pada penggunaan prefiks di-. Dari 32 data yang dianalisis sebanyak 17 kesalahan prefiks di- yang dilakukan oleh mahasiswa. Dalam makalah mahasiswa program studi Pendidikan Bahasa Indonesia, mahasiswa mengalami kesulitan membedakan antara prefiks (awalan) di- dan preposisi (kata depan) di. Tidak hanya pada prefiks $d i$ - tapi juga pada prefiks $k e$-. Dari hasil penelitian ini, pada kesalahan prefiks $d i$ - mahasiswa sering memisahkan dua kata dan preposisi $d i$ mahasiswa sering menggabungkan dua kata. Pada kesalahan konfiks, mahasiswa tidak menggunakan konfiks per-an pada kata yang seharusnya menggunakannya. Pada kesalahan simulfiks mahasiswa memisahkan simulfiks di-per-dengan kata yang mengikutinya. Seharusnya kata dasar disambung dengan simulfiks yang mengawalinya.

\section{SARAN}

Berdasarkan hasil dan simpulan dalam penelitian ini, peneliti memberikan saran sebagai berikut.

1. Bagi dosen, sebaiknya lebih intensif mengajarkan perbedaan antara disebagai prefiks dan $d i$ sebagai preposisi.

2. Bagi mahasiswa, sebaiknya menguasai afiks agar tidak terjadi salah tafsir atau berubahnya makna dalam tulisan yang menggunakan afiks.

3. Bagi peneliti selanjutnya, sebaiknya penelitian seperti ini dikembangkan mengingat dari hasil penelitian ini selain ditemukan kesalahan afiks juga ditemukan beberapa kesalahan ejaan.

\section{DAFTAR PUSTAKA}

Achmad, dkk., (2012). Layanan Cinta: Perwujudan Layanan Prima ++ Perpustakaan. Jakarta: SagungSeto.

Alwi, dkk., 2003. Tata Bahasa Baku Bahasa Indonesia. Jakarta: Balai Pustaka.

Alwi, Hasan., dkk.2005. Tata Bahasa Baku Bahasa Indonesia Edisi Ketiga. Jakarta: Pusat Bahasa dan Balai Pustaka.

Arikunto, S. 2010.Prosedur Penelitian Suatu Pendekatan Praktik. Jakarta:Rineka Cipta.

Chaer, Abdul. 1998. Linguistik Umum. Jakarta: Rineka Cipta. 
Chaer, Abdul. 2007. Linguistik Umum Cetakan Ketiga. Jakarta: RinekaCipta.

Emzir. 2017. Metodologi Penelitian Pendidikan:kuantitatif dan kualitatif: jakarta: PT RajaGrafindo.

Keraf, Gorys. 1984. Diksidan Gaya Bahasa. Jakarta: PT. Gramedia Pustaka Utama.

Lexy,J Moleong. (2008) Metodologi Penelitian Kualitatif, Bandung: PT Remaja Rosdakarya.

Muslich, Masnur. (2009). Melaksanakan PTK (Penelitian Tindakan Kelas) Itu Mudah. Jakarta: PT. Bumi Aksara.

Rohmadi,Mohamad. 2014. Kajian Pragmatik Percakapan Guru dan Siswa dalam Pembelajaran Bahasa Indonesia. PKIP-UNS: Jurnal Paedagogia, Vol.17, No. 1 Tahun 2014.

Ramlan, M. 2009. MORFOLOGI : Suatu Tinjauan Deskriptif. Yogyakarta: C.V. Karyono.

Ramlan. 2012. Morfologi Suatu Tinjauan Deskriptif. Yogyakarta: C.V. Karyono.

Rohmadi, Muhammad, Yakub Nasucha, dan Agus Budi Wahyudi. 2012. Morfologi: Telaah Morfem dan Kata. Surakarta: Yuma Pustaka.

Sugiyono. 2010. Metode Penelitian Pendidikan. Bandung: Alfabeta.

Sugiyono. 2014. Metode Penelitian Pendidikan Pendekatan Kuantitatif, Kualitatif Dan R\&D. Bandung: Alfabeta.

Sugiyono, (2008). Metode Penelitian Kuantitatif Kualitatif dan R\&D. Bandung Alvabeta.

Verhaar, J.W.M. 1984. Pengantar Linguistik. Yogyakarta: Gajah Mada University Press. 